\title{
Towards Social Entrepreneurship in the Village through Village-Owned Enterprises
}

\author{
Muryanti Muryanti \\ Department of Sociology, Faculty of Social and Humanities, \\ Sunan Kalijaga State Islamic University of Yogyakarta, 56281, Yogyakarta, Indonesia \\ Corresponding Author: newsyant@yahoo.com
}

\section{ARTICLE INFO}

\section{Publication Info:}

Research Article

How to cite:

Muryanti, M. (2020). Towards Social Entrepreneurship in the Village through Village-Owned Enterprises. Society, 8(1), 163174.

DOI : 10.33019/society.v8i1.161

Copyright $@$ 2020. Owned by Author(s), published by Society

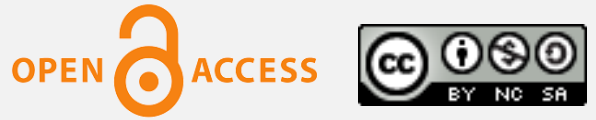

This is an open-access article.

License: Attribution-

NonCommercial-ShareAlike (CC BY-NC-SA)

Received: March 17, 2020;

Accepted: May 19, 2020;

Published: June 23, 2020;

\begin{abstract}
Social entrepreneurship is an important concept for realizing the welfare of rural communities. This concept refers to the dedication of individuals, who have the character of a leader, who collaborates actively with their communities, to realize collective welfare. This research aims to analyze the role of Village-Owned Enterprises (BUMDes) in improving the welfare of rural communities through social entrepreneurship. This research was qualitative. The data collection technique used in this research was the observation. The results of observations are then analyzed, combined, and enriched with secondary data. The results showed that BUMDes is an institution in rural areas, which has an important role in encouraging and supporting the principles of social entrepreneurship in rural communities. However, the various BUMDes activities and innovations have not yet provided significant changes for the village such as job opportunities for rural youth and various economic activities in rural areas to improve the local economy. Strengthening the social system in the village is needed to realize social entrepreneurship comprehensively through the active collaboration of village leaders and the community. Village fund management by BUMDes needs to be continued and evaluated in its implementation.
\end{abstract}

Keywords: BUMDes; Social Entrepreneurship; Village Fund; Village

Copyright ( 2020. Owned by Author(s), published by Society. This is an open-access article under the CC-BY-NC-SA license. 


\section{Introduction}

Rural has an important role in country development. Indonesia can develop its potential through villages. Concerning urban communities, villages can contribute to food, energy, environment, and productive labor migrating to the city. The village is the driving force of the city (Muryanti, 2018). This great potential, which can be developed, is due to a large number of villages in Indonesia. Based on the Regulation of the Minister of Home Affairs of the Republic of Indonesia Number 137 of 2017, the number of villages in Indonesia is 74,957 villages (Abdulsalam, 2019). In the past two years, the number of villages increased by a total of 203 villages.

The villages have great potential. The existence of villages is regulated in the Law of the Republic of Indonesia Number 6 of 2014 concerning Village. Also, other regulations concerning village potential are Government Regulation of the Republic of Indonesia Number 73 of 2005 concerning Urban Village, and Regulation of the Minister of Home Affairs of the Republic of Indonesia Number 66 of 2007 concerning Village Development Planning.

Based on the Law of the Republic of Indonesia Number 32 of 2014 concerning Regional Government, the village is the lowest regional government, which has the authority to regulate and manage local communities. In other words, the village has the autonomy to regulate its territory. Village autonomy is inseparable from the origin and local customs which are recognized and respected in the system of government of The Unitary State of the Republic of Indonesia (Negara Kesatuan Republik Indonesia or NKRI).

The Government of Indonesia through the Ministry of Villages, Disadvantaged Regions and Transmigration has four priority programs to accelerate village development. The four priority programs are Featured Product of Rural Area (Produk Unggulan Kawasan Perdesaan or Prukades, Large-scale Water Reservoirs (Embung), Village-Owned Enterprises (Badan Usaha Milik Desa or BUMDes), and Village Sports Facilities (Sarana Olahraga Desa or Raga Desa). The government allocated village funds to run the four priority programs. In 2019, the government has allocated IDR 70 trillion for village funds (Kementerian Keuangan Republik Indonesia, 2018).

BUMDes are one of the four programs of the Ministry of Villages, Disadvantaged Regions, and Transmigration of the Republic of Indonesia. The main targets of the program are: (1) Local Resources; (2) Management of Productive Economic Business; (3) Strengthening Capacity for Disaster Risk Management; (4) Environmental Conservation, and (4) Strengthening Village Governance. BUMDes encourages and supports villages to be self-reliant to develop village potential through their business entities.

Several villages in Indonesia have succeeded in exploring the potential of their villages as an effort in village development. In-depth research on these successes is needed to be used as a model, especially in the development of BUMDes. This research aims to examine the success of BUMDes in several regions in Indonesia as an institution for driving village development by focusing on the role of BUMDes in driving economic activity in rural areas. Also, BUMDes can encourage the social entrepreneurship of rural communities, which had already been formed before, as an inherent character in the community. BUMDes efforts not only aim to gain economic benefits for rural communities but more than that, the aim is to improve the welfare of rural communities. For example, the availability of jobs and decreasing unemployment in rural areas are a positive value of the village funding program.

\section{Literature Review}

Gregory Dees explained that social entrepreneurship is different from business entrepreneurship (Puspitasari, 2019). Social entrepreneurship has an explicit goal based on a

Copyright (C) 2020. Owned by Author(s), published by Society. This is an open-access article under the CC-BY-NC-SA license. 
movement that is driven by a passion to help others and make changes for the benefit of the community. Social entrepreneurs are those who know capital (human resources), social capital, and social skills, which turn social problems into social innovation. The best way to measure social entrepreneurship is not by calculating the amount of profit generated but at the level where economic activity also generates social values. Also, according to Gregory Dess, social entrepreneurship is a combination of enthusiasm in social activities, which is combined with determination, innovation, and discipline, almost the same as what is developing in the business world. Social entrepreneurship activities are not only for profit but also for how to combine profit-seeking activities with activities aimed at social value.

Social entrepreneurship activities, at the individual level, can reduce the unemployment rate by creating jobs and at the group level, can reduce poverty levels in the community (Firdaus, 2014) and resolve various social problems (education and health). Social entrepreneurship is an effort to find opportunities with small resources but has a spirit of continuous hard work to improve the welfare of the community (Purwani et al., 2018). According to Abu-Saifan (2012), several characteristics of social entrepreneurship are as follows: (1) innovation ability; (2) high dedication; (3) managerial skills; (4) strategic thinking; (5) holistic thinking; (6) leadership ability; (7) high commitment; (8) can look for opportunities; (9) creator; (10) has business content, and (11) persistent in doing business.

\section{Research Methodology}

This research was qualitative descriptive research. Qualitative research is research that studies or interprets phenomena, which are analyzed from the processes and meanings attached to the researcher. This research aims to bring up various meanings in different contexts, including various methods, which include interpretive and naturalistic views of the subjects studied. The results of qualitative research are the processes of meaning from the personal experience of daily research subjects (Denzin \& Lincoln, 2009, p. 2).

This research used secondary data, obtained through newspapers, both online and print newspapers, which review the successes of villages that receive village funds. Also, this research used data obtained from observations in villages that have success in BUMDes business and management. Observation is one of the most basic data collection techniques in research in taking action and interpreting an event and its implications. This technique is used to obtain and knowing general truths and knowledge about community culture, which cannot be obtained through interviews or to enrich the data obtained from interviews. Observation is the process of recording an event using an instrument and recording it for research purposes (Denzin \& Lincoln, 2009, p. 523).

The observation was carried out by observing various activities carried out by BUMDes in several villages in the Special Region of Yogyakarta and Central Java Province, Indonesia, which had succeeded in developing BUMDes. This can be seen from the appropriate development of village infrastructure and following the needs of the village community, the development of the tourist village, diverse business units and managed independently, or the development of the concept of the smart village, and the use of technology among the community to solve problems in the village.

\section{Results \& Discussion}

\subsection{The Role of BUMDes in Rural Areas}

BUMDes is one manifestation of the implementation of the law, related to the management of natural resources on a village scale, which is in line with the 5th principles of Pancasila, 
Social Justice for All the Peoples of Indonesia (Surono, 2017). BUMDes aims to improve the village economy and the welfare of the community (Agunggunanto et al., 2016). Social justice and community welfare together are in line with the concept of social entrepreneurship.

BUMDes are established, managed, and developed by the village. The village also has a role as a facilitator and motivator in improving the quality of the Human Resources management of BUMDes, and the supervisor of the BUMDes program. BUMDes startup capital, as a whole, belongs to the village. But in several villages, the Village Government and the community invested in BUMDes, with a percentage of 51:49 (Ridlwan, 2014). The BUMDes capital is a village asset, which is managed to provide services to the community (Astuti \& Warsito, 2017). In the management of BUMDes, there is a separation for services, asset management, and business development, which results are used to improve the welfare of the village community (Winarto, 2017).

BUMDes has an important role to maintain the spirit of cooperation in the development of national identity. As the results of research conducted by Rika Fatimah in 61 villages in the western part of Indonesia, showed that village empowerment through BUMDes is important to do because it can create competitive, collaborative and adaptive advantages, to sustainable village welfare with the condition of involving the community and considering the character of the village (Kompas.id, 2018a). The purpose of establishing BUMDes is to accelerate economic activity in the village to realize a developed village and increase Village-Generated Revenue (Faedlulloh, 2018). BUMDes brings social and economic changes in the village, not directly to households, but rather at the macro level with an increase in Village-Generated Revenue. This is in line with development in rural areas which have priority in infrastructure development and economic development at the village level (Anggraeni, 2016).

BUMDes also has an important role in carrying out the process of community empowerment, which aims to be a stabilizer, modernizer, innovator, and reduce unemployment (Darwita \& Redana, 2018). However, in the future, family economic development needs to be prioritized, when BUMDes has been able to improve the rural economy at a macro level.

BUMDes' performance is influenced by (1) institutional governance as the main key to success. BUMDes performance is a collective work that influences and is influenced by interrelated village work systems; (2) business sustainability is influenced by the reach and scale of the business, which can survive because it serves the local needs of the local community; (3) BUMDes, which grow and develop based on local wisdom and solidarity are stronger and more robust in organizational sustainability compared to commercial business units (Diartho, 2017).

Activities aimed at increasing productivity and economy in the village, one of which is the management of tofu production was facilitated by stakeholders. Tofu's liquid waste management and biogas utilization are ongoing and sustainable using technology. The management process was changed because previously the process was carried out by the central government and regional governments using the Waste Water Treatment Plant (Instalasi Pengolahan Air Limbah or IPAL), which did not consider the economic feasibility analysis (Shaffitri et al., 2016).

Other activities developed by BUMDes are diverse. Some business units that have been developed include a one-stop-shop (warung serba ada or waserda) accompanied by accommodating the original village production (Darwita \& Redana, 2018), village market development, development of cooperatives that sell wholesale and retail goods, savings and loan units through cooperatives, development of village tourism, development of agricultureindustry-transportation, as well as assisting home industry, agro-industry or inland fisheries

Copyright (C 2020. Owned by Author(s), published by Society. This is an open-access article under the CC-BY-NC-SA license.

https://doi.org/10.33019/society.v8i1.161

166 
(Ridlwan, 2014), clean water management, village infrastructure development, assisting home industry business groups, truck mixer rentals (Winarto, 2017). In several villages, BUMDes runs various Islamic-based activities. The activity is expected to provide overall benefits, by promoting a sense of kinship in conducting business following Islamic sharia (Pradesyah \& Albara, 2018). Sharia-based economic activities consist of interest-free savings and loans, but only pay profit-sharing according to operating results.

These activities can increase economic activities in the village with faster money turns. At the individual level, families can meet their basic needs and open business opportunities for each individual to develop their products in innovative and creative ways. At the community level, BUMDes can create new jobs or update existing jobs using technology that attracts young people. This employment opportunity can reduce unemployment in rural areas. Changes that occur at the level of individuals, groups, and communities are a form of social entrepreneurship concepts that grow in the village.

At present, BUMDes has been positioned as a village economic institution that has a role in community welfare, village, and village governance. Well-managed BUMDes will support the local, regional, and national economies. BUMDes as a new institution in rural areas has a positive contribution to economic development in rural areas, but the implementation process still has some problems that need to be resolved in the future. Several problems experienced by BUMDes, including service quality, organizational management, lack of business types, and low participation of rural communities in BUMDes management (Agunggunanto et al., 2016). Thus, in the process of developing BUMDes, it must involve the entire community, not just village officials, by becoming a member/owner of BUMDes, as applied in the cooperative economic system (Faedlulloh, 2018).

It is very necessary to conduct supervision by related parties under the authority of the central government or regional government, to fulfill the village's right to natural resources at the village scale. In its implementation, technical provisions need to be regulated to conduct monitoring and evaluation and provide guidance to villages (Surono, 2017). At the local level, village governments have a strong role in managing BUMDes as supervisors and decisionmakers. The quality of service and management of BUMDes organizations needs to be improved and professional workers are needed to make BUMDes a professional institution (Anggraeni, 2016).

Internal and external supervision of BUMDes can be carried out. Internal control is carried out by the Regulatory Body (Badan Pengawas), while external control is carried out by the Community Empowerment Agency (Badan Pemberdayaan Masyarakat). The Regulatory Body, in conducting supervision, uses administrative data periodically following the annual work program. The Community Empowerment Agency only played a role in the initial process of establishing and facilitating BUMDes with government programs. In its implementation, the role of the two supervisors has not been optimal and requires good coordination to improve the BUMDes in empowering and contributing to village development (Astuti \& Warsito, 2017). Increasing the empowerment and availability of jobs as a result of the performance of BUMDes can certainly improve social entrepreneurship in the village.

\subsection{Social Entrepreneurship through BUMDes in the Village}

BUMDes activities are the implementation of the concept of social entrepreneurship to develop village potential. In addition to generating economic benefits, BUMDes also acts as a communication forum, maintaining motivation to work, empowerment forums, and forums to increase solidarity for rural communities. BUMDes also has a role to create innovation to reduce

Copyright (C 2020. Owned by Author(s), published by Society. This is an open-access article under the CC-BY-NC-SA license. 
unemployment. BUMDes assists the village government in managing village funds and developing natural and human resources in the village.

Latukan Village, Karanggeneng District, Lamongan Regency, East Java Province, Indonesia, one of the villages that have successfully applied the concept of entrepreneurship in managing village funds. This village is known as an independent village. Village funds obtained from the central government are only used as supporting funding for village development. In other words, village development uses village independent funding sources.

This village with a population of 1,500 families (approximately 5,000 inhabitants) has featured potential from agricultural production. Staple crops are not too different from other villages consisting of rice and secondary crops (palawija). Whereas the commercial crops planted by farmers, which provide many benefits are yellow and red watermelons. The watermelon planting area is 374,452 hectares. With such a planting area, of course, farmers get maximum profit in the harvest season.

Besides, Latukan Village community activities increasingly dynamic with the various types of businesses managed by BUMDes (Kompas.id, 2018b). BUMDes in Latukan Village has a water company, a periodic livestock program, and repair and rental services for agricultural production equipment such as planting machines, harvesting machines, and tractors. Clean water sources are from Groundwater (Air Bawah Tanah or ABT) and from the Bengawan Solo River, which is processed using a Water Purifier Installation (Instalasi Penjernih Air or IPA). Water from rivers is collected in water storage ponds and then processed using a Water Purifier Installation (Instalasi Penjernih Air or IPA) and then distributed to the community. The community pays Rp1,200 per cubic meter $\left(\mathrm{m}^{3}\right)$ in using this service. BUMDes get profit from this business Rp1,250,000 per month.

BUMDes also manages village markets and sells featured products for small and medium businesses consisting of snacks with the basic ingredients of banana blossom. Then, the banana blossom is processed by the community into chips, sticks, jenang (porridge served with brown sugar or coconut milk), and ice cream. The village market has 67 small merchant stalls, with a retribution fee of $\mathrm{Rp} 500$ per merchant. Income from retribution provides benefits to the village of $\operatorname{Rp} 3,000,000 /$ month. The capital loan is limited to $\operatorname{Rp~3,000,000~for~each~merchant,~which~is~}$ allocated to 200 merchants and the local community. Especially for small and medium businesses, capital loans must be returned within 110 days. Village market assets reached Rp110,000,000 and total bad loans Rp30,000,000.

BUMDes in Latukan Village not only encourage community economic activities, develop village potential, and increase village turnover, but also sell Micro and Small and Medium Enterprises (MSMEs) products through BUMDes stall located near the Village Office. BUMDes also cooperates with the Farmers Group Association (Gabungan Kelompok Tani or Gapoktan) to provide agricultural equipment rental services. The management of agricultural production equipment contributes income to the village of Rp.33,000,000/year or $20 \%$ of the turnover of rental and repair services.

Village funds received by Desa Latukan amounted to a total of Rp283,000,000 in 2015. In 2016, village funds received amounted to a total of Rp634,000,000. In 2017, village funds received amounted to Rp809,000,000. Village potential management is carried out with various productive activities and has been able to generate revenues of Rp2.57 billion. This result is about half of the total revenue of Rp1.46 billion from various funding sources received such as village funds and revenue sharing from taxes and retribution from the regency.

The village government also empowered the community with loans for livestock businesses to farmers. In 2016, the goat livestock business loan reached Rp.52,500,000, provided that one

Copyright (C) 2020. Owned by Author(s), published by Society. This is an open-access article under the CC-BY-NC-SA license. 
person received a loan of Rp3,500,000, spread over 15 Neighborhood Groups, each for 1 person. Loans can be returned by $80 \%$. The goats were bought by the villagers for Rp2,000,000 per goat. In this village, there are 85 beef cattle breeders, 55 goat breeders, and fishery commodities (tilapia 2.4 tons/year, catfish 1 ton/year, and milkfish 13 tons/year). The diversity of farmers' business activities increases the velocity of village funds managed by BUMDes (Kompas.id, 2018b).

Social entrepreneurship in Latukan Village can be seen from the activity of BUMDes that conducts economic development in the village. These various kinds of activities can drives economic activities in rural areas at the level of individuals, groups, or village communities. At the individual level can create jobs, reduce unemployment, and improve family welfare. At the group level, it consists of economic activities organized by community organizations in villages that work together with BUMDes, such as Gapoktan, Karang Taruna, Dasawisma, or Posyandu, as a collective activity in realizing social values. At the community level, as a whole, can reduce rural poverty, resulting from social entrepreneurship activities at the individual and group level.

Economic activity and social entrepreneurship in Latukan Village is a success in managing village funds, one of which is managed through BUMDes. In different contexts, the following villages succeeded in developing village economic activities and were able to strengthen entrepreneurship in the village.

1) Pangkahwetan Village, Ujungpangkah District, Gresik Regency, East Java Province (Kompas.id, 2018c).

A. Economic Development

a) Mangrove ecotourism development and creation photo spots for tourists.

b) Nyamuk Island tourist area development (Gili Grasakan).

c) Seafood culinary development (crab curry, lobster, white-eel tailed catfish spices, and grilled fish) near the pier.

d) Periodical events such as the Bengawan Solo Estuary Festival (Panjat Pinang (climb to the top of a greased pole), paddle racing, ornamental boats, kites).

e) Cultural events development such as the selection of male (Reang) and female (Eson) tourism ambassadors.

B. Social Entrepreneurship

a) Tourism villages' development can increase job opportunities and reduce unemployment.

b) BUMDes has a savings and loan business unit as well as payment and transfer services to facilitate the economic activities of the community.

2) Ciawigajah Village, Beber District, Cirebon Regency, West Java Province (Kompas.id, 2018d)

A. Economic Development

a) Village Water Company development which produces clean water and economical compared to using well water for daily needs.

b) Sales of MAKMUR-QUA brand bottled water.

c) The opening of BUMDesMart, which accommodates the products of the creativity of the village community (various sweet potato products).

d) Lease on village land management through auctions to the community with the maximum area of leased land of 1 hectare.

e) Goat farms development. 
f) Rafting tourism area development on the Cimanis River with a length of $3 \mathrm{~km}$.

g) Household waste management by the village government.

B. Social Entrepreneurship

BUMDes management which includes the development of village tourism, the village water company, village household waste management, and BUMDesMart can increase employment opportunities for the village community.

3) North Baumata Village, Taebenu District, Kupang Regency, East Nusa Tenggara Province (Kompas.id, 2018e)

A. Economic Development

a) The Garden of Eden development with horticultural crops, secondary crops (palawija), coffee, candlenut, coconut, areca nut, jackfruit, and mango along the arid village road can green the village and at the same time provide economic results.

b) Agricultural facilities and infrastructure construction (bore well pump, hoses, water taps, construction of cow pens, construction of agricultural warehouses) and purchase of agricultural equipment (corn milling machines and grated coconut machines).

c) Village road infrastructure development to facilitate economic activity.

d) BUMDes development to drive the village economy by buying mobile tents, plastic chairs, light bulbs, and agricultural equipment kiosks.

B. Social Entrepreneurship

a) The Garden of Eden is an innovative effort from the government in mobilizing the community in the cultivation of agriculture collectively (the use of village land that is leased to the community for mutual prosperity).

b) Labor-intensive projects in village infrastructure development can increase employment and reduce unemployment.

c) Reducing unemployment by developing BUMDes through various agricultural businesses.

4) Sanankerto Village, Turen District, Malang Regency, East Java Province (Kompas.id, 2018f)

A. Economic Development

a) Ecotourism and bamboo arboretum development and embung (reservoir) for agriculture to maintain agricultural water sources and clean water sources.

b) Tourist attractions in the agricultural reservoir are artificial lakes (swimming pools, water bicycles, and small boats).

c) A bamboo arboretum is an educational object because of the diversity of bamboo species planted, which originates from all regions in Indonesia and become a source of water for maintaining ecological balance, daily drinking water, and irrigation.

d) Development of village infrastructure, which includes drainage, supporting walls for roads, duiker plates, culverts, and concrete rebates.

B. Social Entrepreneurship

a) Labor-intensive infrastructure development can increase employment in the village.

b) Arboretum and Ecotourism development can encourage creative labor in the village to develop tourism.

c) New employment resulting from tourism development is related to the home industry and entrepreneurship. 
5) Karang Bunga Village, Mandastana District, Barito Kuala Regency, South Kalimantan Province (Kompas.id, 2018g)

A. Economic Development

a) Local rice cultivation of Karang Dukuh and Siam Unus varieties.

b) Siam Banjar Orange Cultivation. The harvested fruit then processed and made into ice cream products that will be sold through BUMDes.

c) BUMDes savings and loan business units development and provision of capital to farmers for local rice cultivation during the planting season and repaid by farmers during the harvest season.

d) Various businesses developed by BUMDes include buying and selling grain, clean water supply services, multipurpose building management, cattle fattening, and orange ice cream production.

B. Social Entrepreneurship

a) Various businesses developed by BUMDes can increase employment in the village.

b) Local crop cultivation can create new jobs and increase the creativity of farmers to increase income.

These villages are the best examples for villages, which have succeeded in managing village funds, provided by the central government for village development. Village funds are used for village development, which in its management is carried out by establishing BUMDes institutions. Village development is carried out through various activities, including the development of village tourism and culinary, water resources management, agricultural and livestock productivity improvement, village resource management, infrastructure development, and management of various businesses.

Village economic development does not only aim to increase income for the community and village institutions, but also to develop social entrepreneurship in the village. The growth of the concept of social entrepreneurship due to the mechanism of community solidarity in rural areas is still relatively high compared to urban communities. This has implications for the emergence of a movement to achieve mutual prosperity.

Increased rural development activities have led to reduced migration from rural to urban areas due to the availability of jobs that attract young people in the village, increased quality of the village's Human Resources (HR), and creativity in developing various businesses. However, if it refers to the concept of social entrepreneurship, the increase in village development has not been significant. That only covers a small part of the concept of social entrepreneurship that can be applied in villages.

The concept of social entrepreneurship consists of (1) knowledge, social capital, and social skills that can solve social problems into social innovation; (2) social activities that combine with determination, innovation, and discipline; (3) finding opportunities with minimal resources accompanied by the spirit of hard work to improve the welfare of the community; (4) innovator, discipline, high dedication, creator, and leadership characters cannot be done in villages through this program. Some of the reasons are because the implementation of this program is still in a short time (approximately 5 years), the target program or activity is still in the short term (not sustainable for the long term), the program is pragmatic (emphasizing productive activities in the short term rather than the development of human resource quality improvement programs in villages in the long term), development of the character of social entrepreneurship and community involvement in this program has not been significant because there is more involvement of village officials compared to village communities.

Copyright (C 2020. Owned by Author(s), published by Society. This is an open-access article under the CC-BY-NC-SA license. 


\section{Conclusion}

Various activities funded from village funds are the initial stage in the process of developing social entrepreneurship in the village. A sustainable program is needed to maintain continuity of activities. Developing social entrepreneurship is a long process and related to human resources and natural resources in rural areas. Innovation, supervision, and sustainability of the program need to be done to achieve the target.

Social entrepreneurship in the village can be developed because basically, the village community has the character of a strong collective awareness to achieve mutual prosperity. Collectivity can always be maintained if the social system in the village supports it. Social entrepreneurship in the village, basically, just needs to be encouraged because of the resources that are already available. Village funds managed by BUMDes are an encouragement to strengthen social entrepreneurship. Early progressive efforts must be recognized as an opportunity to realize the welfare of the community and the welfare of the rural community affecting the national social system.

\section{Acknowledgment}

The author would like to thank all who provided assistance and information during the research conducted.

\section{Declaration of Conflicting Interests}

The author declared no potential conflicts of interest concerning the research, authorship, and/or publication of this article.

\section{References}

Abdulsalam, H. (2019, March 25). Saat Banyak Kelurahan Ingin Jadi Desa Demi Dapat Dana Desa. Retrieved from https://tirto.id/saat-banyak-kelurahan-ingin-jadi-desa-demi-dapat-danadesa-dj6y

Abu-Saifan, S. (2012). Social Entrepreneurship: Definition and Boundaries. Technology Innovation Management Review, 2(2), 22-27. https://doi.org/10.22215/timreview/523

Agunggunanto, E. Y., Arianti, F., Kushartono, E. W., \& Darwanto, D. (2016). Pengembangan Desa Mandiri Melalui Pengelolaan Badan Usaha Milik Desa (Bumdes). Jurnal Dinamika Ekonomi \& Bisnis, 13(1), 67-81. https:/ / ejournal.unisnu.ac.id/JDEB/article/view/395

Anggraeni, M. R. R. S. (2016). Peranan Badan Usaha Milik Desa (Bumdes) Pada Kesejahteraan Masyarakat Pedesaan Studi Pada Bumdes Di Gunung Kidul, Yogyakarta. MODUS, 28(2), 155-167. https:/ / doi.org/10.24002/modus.v28i2.848

Astuti, P., \& Warsito, W. (2017). Pelaksanaan Fungsi Pengawasan BUMDes Desa Ponggok Kecamatan Polanharjo Kabupaten Klaten. Journal of Politic and Government Studies, 6(2), 291-300. https:/ / ejournal3.undip.ac.id/index.php/jpgs/article/view/16127

Chintary, V. Q., \& Lestari, A. W. (2016). Peran Pemerintah Desa dalam Mengelola Badan Usaha Milik Desa (BUMDes). JISIP: Jurnal Ilmu Sosial dan Ilmu Politik, 5(2), 59-63. https://publikasi.unitri.ac.id/index.php/fisip/article/view/244

Darwita, I. K., \& Redana, D. N. (2018). Peranan Badan Usaha Milik Desa (BUMDes) Dalam Pemberdayaan Masyarakat Dan Penanggulangan Pengangguran Di Desa Tejakula Kecamatan Tejakula Kabupaten Buleleng. Locus, 9(1), 52-60. https:/ / ejournal.unipas.ac.id/index.php/LOCUS/article/view/79 
Denzin, N. K., \& Lincoln, Y. S. (2009). Handbook of Qualitative Research (Terjemahan ed.). Yogyakarta, Indonesia: Pustaka Pelajar.

Diartho, H. C. (2017). Strategi Terhadap Pengembangan Kelembagaan BUMDESA di Kabupaten Jember. Ekonomikawan: Jurnal Ilmu Ekonomi dan Studi Pembangunan, 17(2), 200-218. https:// doi.org/10.30596/ekonomikawan.v17i2.1801

Faedlulloh, D. (2018). BUMDes dan Kepemilikan Warga: Membangun Skema Organisasi Partisipatoris. Journal of Governance, 3(1), 1-17. https:// doi.org/10.31506/jog.v3i1.3035

Firdaus, N. (2014). Pengentasan kemiskinan melalui pendekatan kewirausahaan sosial. Jurnal ekonomi dan Pembangunan, 22(1), 55-67. https:/ / doi.org/10.14203/JEP.22.1.2014.69-81

Kementerian Keuangan Republik Indonesia. (2018). INFORMASI APBN 2019. Direktorat Jenderal Anggaran. Retrieved from https://www.kemenkeu.go.id/media/11226/bukuinformasi-apbn-2019.pdf

Kompas.id. (2018a, September 17). Desa Simpan Potensi Besar. Retrieved from https://kompas.id/baca/utama/2018/09/17/desa-simpan-potensi-besar/

Kompas.id. (2018b, April 25). Menggali Semua Potensi Ekonomi Desa. Retrieved from https://kompas.id/baca/nusantara/2018/04/25/menggali-semua-potensi-ekonomidesa/

Kompas.id. (2018c, January 17). Menjual Pesona Muara Bengawan Solo. Retrieved from https://kompas.id/baca/nusantara/2018/01/17/menjual-pesona-muara-bengawansolo/

Kompas.id. (2018d, March 28). Kreativitas Warga Memperbaiki Nasib. Retrieved from https:/ / kompas.id/baca/nusantara/2018/03/28/kreativitas-warga-memperbaiki-nasib/

Kompas.id. (2018e, March 14). Bangun Hidup Dari Dana Desa. Retrieved from https:/ / kompas.id/baca/nusantara/2018/03/14/bangun-hidup-dari-dana-desa/

Kompas.id. (2018f, May 9). Arboretum Bambu Dari Sanankerto. Retrieved from https:/ / kompas.id/baca/nusantara/2018/05/09/arboretum-bambu-dari-sanankerto/

Kompas.id. (2018g, July 17). Nilai Tambah Produk Unggulan Desa. Retrieved from https:/ / kompas.id/baca/nusantara/2018/07/17/nilai-tambah-produk-unggulan-desa/

Muryanti, M. (2018). Pedesaan dalam Putaran Zaman: Kajian Sosiologis Pedesaan, Petani dan Pertanian. Yogyakarta: Pustaka Pelajar.

Pradesyah, R., \& Albara, A. (2018). Pengelolaan Potensi Badan Usaha Milik Desa (Bumdes) Berbasis Syariah Di Desa Rambung Sialang Hulu Kecamatan Sei Rampah Kabupaten Serdang Bedagai Sumatera Utara. JURNAL PRODIKMAS Hasil Pengabdian Kepada Masyarakat, 2(2), 156-164.

http://jurnal.umsu.ac.id/index.php/prodikmas/article/view/2476

Purwani, D. A., Partini, P., \& Wastutiningsih, S. P. (2018). Tantangan Sociopreneurs Yogyakarta Di Era Communication 3.0. Profetik: Jurnal Komunikasi, 11(1), 12-25. https://doi.org/10.14421/pjk.v11i1.1420

Puspitasari, D. C. (2019, September). Kewirausahaan Sosial: Dalam Konsep Dan Terapan. Diskusi Umum. Yogyakarta, Indonesia.

Ridlwan, Z. (2014). Urgensi BUMDes dalam Pembangunan Perekonomian Desa. Fiat Justicia Jurnal Ilmu Hukum Fakultas Hukum Universitas Lampung, 8(3), 424-440. https:// doi.org/10.25041/ fiatjustisia.v8no3.314

Shaffitri, L. R., Syaukat, Y., \& Ekayani, M. (2016). Peranan BUMDes dalam Pengelolaan Limbah Cair Tahu dan Pemanfaatan Biogas. RISALAH KEBIJAKAN PERTANIAN DAN LINGKUNGAN: Rumusan Kajian Strategis Bidang Pertanian dan Lingkungan, 2(2), 136-143. http://journal.ipb.ac.id/index.php/jkebijakan/article/view/10984

Copyright (C 2020. Owned by Author(s), published by Society. This is an open-access article under the CC-BY-NC-SA license. https://doi.org/10.33019/society.v8i1.161

173 
Surono, A. (2017). Peranan Hukum Dalam Pengelolaan Sumber Daya Alam Skala Desa Oleh Badan Usaha Milik Desa (Bumdes) Dalam Meningkatkan Kesejahteraan Masyarakat Desa. Jurnal Rechts Vinding: Media Pembinaan Hukum Nasional, 6(3), 459-478. https://rechtsvinding.bphn.go.id/ejournal/index.php/jrv/article/view/195

Winarto, B. (2017). Peranan Bumdes "Mandiri" Dalam Meningkatkan Ekonomi Masyarakat Desa Joho, Kecamatan Purwantoro (Doctoral Dissertation). Ponorogo: Universitas Muhammadiyah Ponorogo. Retrieved from http://eprints.umpo.ac.id/3615/

\begin{abstract}
About the Author
Muryanti, obtained her Doctoral degree from IPB University, Indonesia, in 2017. The author is an Assistant Professor at the Department of Sociology, Faculty of Social and Humanities, Sunan Kalijaga State Islamic University of Yogyakarta, Indonesia.

E-Mail: newsyant@yahoo.com
\end{abstract}

